\title{
AGRICULTURAL INFRASTRUCTURE DEVELOPMENTIMPERATIVE FOR SUSTAINABLE FOOD PRODUCTION: A ZIMBABWEAN PERSPECTIVE
}

\author{
Watson Munyanyi, Lecturer \\ Great Zimbabwe University, Masvingo, Zimbabwe \\ E-mail: wmunyanyi@hotmail.com
}

\begin{abstract}
The agricultural sector in Zimbabwe is a critical sector in terms of economic growth and development. However the sector has been experiencing some setbacks in recent years. This paper sought to examine the effects of infrastructure development in the agricultural sector on sustainable food production. Through questionnaires, observations and focus group discussions, information was gathered from the Zimuto district in Masvingo Province. The data collected was analyzed through both qualitative and quantitative data analysis techniques. The research revealed that there is an unpleasant state of infrastructure in the resettled farms. The fast track land reform programme implemented by the Zimbabwean government had a negative impact on farms infrastructure and equipment. An investment in infrastructure is thus required to ensure that there is agricultural productivity. In line with existing literature the challenges that farmers face can be rectified by infrastructure development. A multi sectorial participation in infrastructure development is required.
\end{abstract}

\section{KEY WORDS}

Sustainable food production; Infrastructure; Agricultural productivity; Economic growth.

During the period prior to 2009, Zimbabwe, experienced what arguably the worst economic meltdown in history. Basic commodities, fuel and foreign currency became scarce while infrastructure dilapidated owing to underutilization and lack of proper maintenance. Once labeled the "bread basket" of Africa, the country went it a severe food crisis due to unreliable supply of low cost inputs, limited access to credit, market information and research and the land reform (UN, 2010). Limited capacities to mobilize capital for equipment and vulnerability to climate change have also been cited in literature as causes of the Zimbabwean food crisis. At independence, in 1980, Zimbabwe inherited from Rhodesia an agricultural base characterized by a high degree of government intervention thorough indirect stimulation and interference (Makamure et al, 2001).

Over the decades, prior to attainment of independence, the colonial governments have helped shape a prosperous commercial farming sector, financing essential infrastructure, providing direct and indirect subsidies, and helping to create supportive marketing and credit systems (Seidman , 1982). According to Seidman (1982), by 1980, 6000 commercial farmers produced $14 \%$ of the Gross Domestic Product (GDP), 95\% of all marketed agricultural produce and about 33\% of the nation's exports. Recent trends in agricultural national yield have shown a downfall in production levels with the national yield for maize dropping to below half a tonne per hectare and wheattotal annual output fell from 325000 tonnes in 1990 to 18500 tonnes in 2008 according to the Ministry of Agriculture, Mechanization and Irrigation Development production statistics in UN(2010).

The land reform programme whichculminated in 1980 after the signing of the Lancaster House Agreement took the fast track mode in 2000 where a sizeable number of white commercial farmers were replaced by black commercial and subsistence farmers. The fast track land reform programme presented a number of since the government urgently needed to capacitate the ministry responsible for agriculture in terms of human, material, and financial resources to carry out land information management, land auditing, and general farm inspections. According to analysts the government's land reform programme and the subsequent collapse of the agricultural sector, which once provided jobs and was the country's main source of export revenues and foreign exchange, are seen as the prime cause of the prolonged economic crisis. 


\section{CONCEPTUAL FRAMEWORK}

Most Africans in poverty live in rural areas.In the Sub-Saharan Africa, it is estimated that 273 million people live on less than one US dollar a day, with $76 \%$ of them living in rural areas (Chen and Ravallion 2007). Zimbabwe's agricultural sector has long been key to its economic stability and growth and only does it form the basis of the direct and indirect livelihoods of almost $70 \%$ of the population, but economic growth is also directly linked to the performance of this sector. However the agricultural sector in Zimbabwe has experienced dramatic downfall leaving many in extreme poverty and malnutrition. According to the 2010 MDG Status Report, the proportion of people in Zimbabwe living below the Food Poverty Line (FPL) increased from $29 \%$ in 1995 to $58 \%$ in 2003, while an estimated 1,3 million people were forecasted to be food insecure at the peak of food insecurity in February and March 2011 (UN, 2010). The level of food insecurity for 2012/2013 represented a 7\% increase from $2011 / 2012$ where $12 \%$ of the rural population was food insecure.

Table 1 - The level of food insecurity*

\begin{tabular}{|c|c|c|c|}
\hline Province & $\begin{array}{l}\% \text { Food } \\
\text { Insecurity } \\
2011 / 12\end{array}$ & $\begin{array}{l}\% \text { Food } \\
\text { Insecurity } \\
2012 / 13\end{array}$ & Food Insecure Population 2012/13 \\
\hline Manicaland & 14 & 15 & 209,364 \\
\hline Mashonaland Central & 10 & 17 & 198,065 \\
\hline Mashonaland East & 8 & 10 & 113,878 \\
\hline Mashonaland West & 7 & 16 & 159,502 \\
\hline Masvingo & 16 & 28 & 378,046 \\
\hline Matebeleland North & 16 & 30 & 155,837 \\
\hline Matebeleland South & 16 & 30 & 213,338 \\
\hline Midlands & 11 & 17 & 217,178 \\
\hline National & 12 & 19 & $1,667,618$ \\
\hline
\end{tabular}

*Source: International Federation of Red Cross Red Crescent Societies, 2012.

Clearly more needs to be done to raise agricultural productivity, to relieve the poverty and hunger of rural people and to increase food production that will tend to bring down the cost of food, and ensure sustainable food production and agricultural productivity. A major determinant of agricultural productivity growth is infrastructure (Gajigo and Lakuma, 2011). The three types of agricultural infrastructure according to Gajigo and Lakuma (2011) are road networks, irrigation technology and post-harvest storage technology. While a myriad of solutions are available to avert the Zimbabwean food crisis and attain sustainable food production, this papers seeks to establish the relationship between financing essential agricultural infrastructure and food productivity levels hence sustainable food production.

\section{LITERATURE REVIEW}

Sustainable Agriculture. Sustainable agriculture is a process of learning and adaptation (Pretty, 1995). Empirical evidence indicates that there are many examples of food deficit areas that became food surpluses areas after the adoption of sustainable agriculture (Hinchcliffe et al, 1996; Bunch and Lopez, 1996). As illustrated by Pretty et al (1997), the intersection of sustainable food production, entitlements and natural resources, guided by a conducive policy environment is food security. According to Schneider and Gugerty (2011), evidence suggests that there are multiple pathways through which increases in agricultural productivity can reduce poverty, including real income changes, employment generation, rural non-farm multiplier effects, and food prices effects. However, barriers to technology adoption, initial asset endowments, and constraints to market access may all inhibit the ability of the poorest to participate in the gains from agricultural productivity growth.

Agricultural Infrastructure. A major source of competitiveness in agricultural value chains and sustainable food production is access to affordable physical infrastructure: according to Warner and Kahan (2008). This includes infrastructure that: supports on-farm 
production like irrigation, energy, transportation, pre- and post-harvest storage; ensures efficient trading and exchange including telecommunications and covered markets; adds value to the domestic economy like agro-processing and packaging facilities, and enables produce to move rapidly and efficiently from farm-gate to processing facilities and on to wholesalers for example transportation and bulk storage.

Agricultural infrastructure thus includes all of the basic services, facilities, equipment and institutions needed for efficient functioning of the food and fiber markets (Venkatachalam, 2003). Empirical evidencesuggeststhat a three to four fold increases in infrastructure investment, reduces poverty by 0.6 to $1 \%$ annually (Besely \& Byrgess 2003).

Infrastructure and competitive advantage. Infrastructure in the agricultural sector enhances the "comparative advantage" of the region where infrastructural investment is made (Venkatachalam, 2003). Studies by Ahmed and Hussain (1990) demonstrated that fertilizer use in the agricultural sector increased with the improvement in the quality of roads. Fan and Hazell (2000) modeled agricultural output as a function of traditional farm inputs, technology, infrastructure and time. The significant and positive trend in the model suggested the existence of important but missing technology and infrastructure variable in the model. This is supported by Rostow (1960) who argues that improvement in infrastructure is considered as a necessary precondition for capital formation and increase in the production and productivity. Boosting agricultural productivity can help to address a raft of problems besetting the continent; food security and hunger, poverty and economic competitiveness (Gajigo and Lukoma, 2011).Using aggregate agricultural production data from 47 developing and 19 developed countries, Antle (1983) observed a strong positive relationshipbetween infrastructure development an aggregate agricultural productivity (Antle, 1983). Bhatia (1999) alsoestablished a positive relationship between composite index of rural infrastructure in 15 states of India and level of per hectare yield of food grains and also value of output from Agriculture.

Agricultural competitiveness and economic growth. Agricultural growth also benefits rural and urban consumers alike by driving down food prices. The poor typically spend a high share of their income on food and therefore benefit from increases in food production that reduce prices (Diao et al , 2007).A large body of empirical studies of the green revolution in Asia demonstrates how agricultural growth reached many small farms and raised large numbers of people out of poverty (Rosegrant and Hazell 2000. In addition studies undertaken have also shown that there is a positive relationship between agricultural growth and overall economic growth.Agriculture has a strong spillover effect on Gross Domestic Product (GDP), through the service and the manufacturing sectors and in Sudan, crop production contributes approximately 45 per cent of the GDP originating in agriculture, livestock contributing most of the remainder, with forestry and fishery contributing just over 5 per cent (UNDP Sudan, 2006). Communal agriculture, in particular, plays a dominant role in Zimbabwe since the country's economy is largely agriculture-based and the majority of the population lives in the rural areas (Luebker, 2008).

Agriculture and infrastructure in Zimbabwe. The agricultural sector in Zimbabwe has been performing poorly for over a decade due to poor rains, structural challenges, and consecutive years of drought, and as a consequence poor harvests. According to the UN (2010) the situation in Zimbabwe was exacerbated by the fast track land reform and the subsequent need for investment in the development and rehabilitation of irrigation systems, and post-harvest infrastructure that followed. The shortage of foreign currency that characterized the period affected the availability of repair and maintenance workshops close to the farmers; and supply of spare parts on the local market. The result was widespread hunger and increase in poverty levels.Lack of capacity by the irrigation industry, equipment suppliers and contractors to provide services led to low productivity, while lack of postharvest infrastructure led to a high level of post-harvest losses. Existing literature supports that liberalization of the agricultural sector, accompanied by increased infrastructural development would improve efficiency and equity in Zimbabwe.Dobermann and Nelson (2013) states that harvest and postharvest technologies save labor reduce grain losses and improve product quality. Fuglie et al (2012) however adds that the technological innovations, 
investments in infrastructure and supporting policies, including subsidies which were effective in some regions have been laggingbehind, particularly Sub-Saharan Africa.

\section{METHODOLOGY, EMPIRICAL FINDINGS AND DISCUSSIONS}

Data collection. Because of the nature of the study, the study employed focus group discussion, questionnaires and field observations to collect data. The study was centered on the Model A2 farmers who emanated from the fast track land reform programme. While the sizes of the model A2 farms vary from region to region, the average size of a Model A2 farm is 320 hectares. To select the sample for research, purposive sampling was used, based on the category of farm size the farmer fell into. A total of 15 farms were identified in Masvingo Province's Zimuto District. This area was chosen because of the higher concentration of Model A2 farmers and fairly good rainfall patterns to eliminate the effects of erratic rainfall patterns. Two focus group discussions were conducted. In addition and to aid in triangulation, questionnaires were also administered to farmers in the chosen region. Direct field observations were conducted as a way of complementing and confirming the veracity of the information gathered through questionnaires and discussions.

Data analysis. Data collected from focus group discussion was analyzed qualitatively through content analysis while data from questionnaires were analyzed using Statistical Package for Social Studies (SPSS) version 16.0. This analysis enabled the generation of descriptive statistics on the responses given.

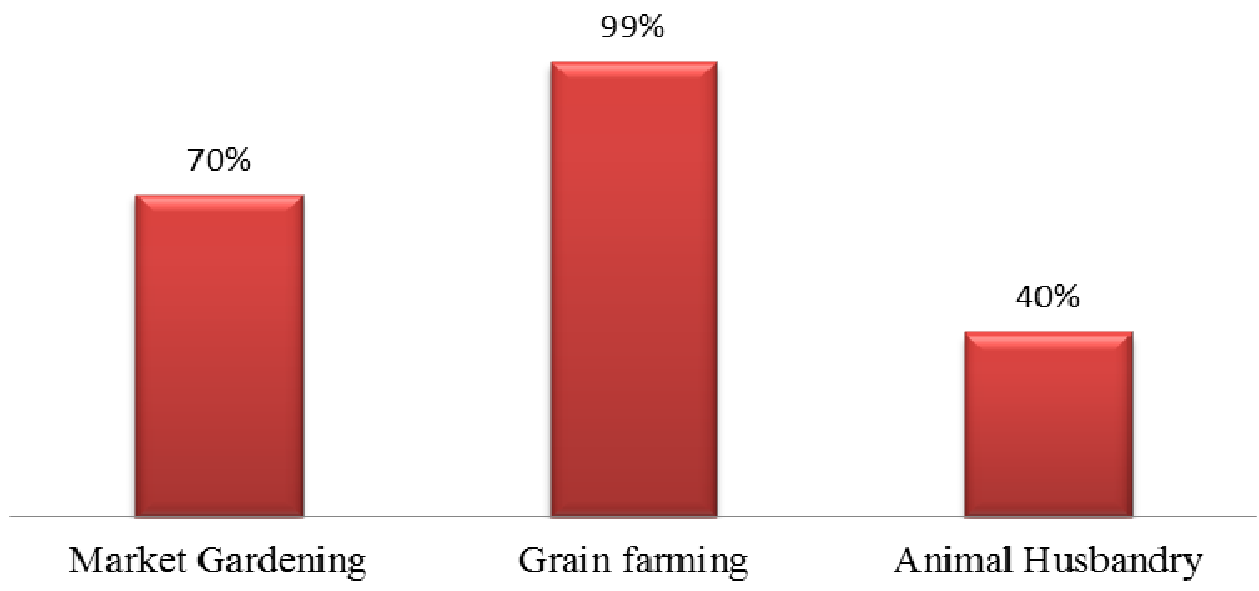

Figure 1 - Type of farming undertaken

\section{- Tarrcd Road \\ $\checkmark$ Maintained Gravel Road \\ - Tarrcd Strip road \\ - Unmaintained Gravel Traits}

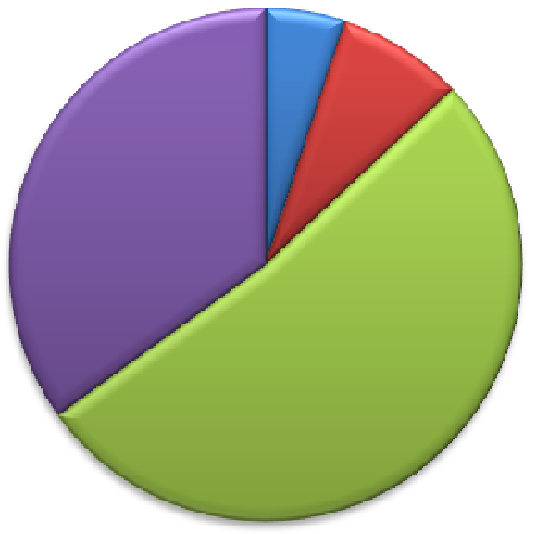

Figure 2 - Accessibility to farms

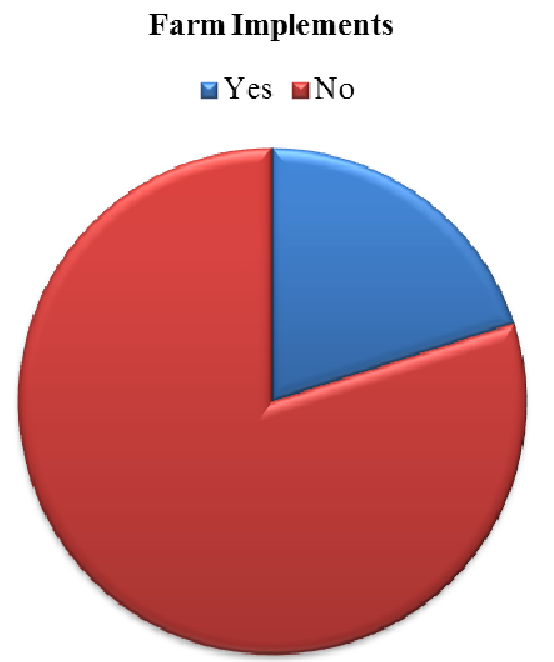

Figure 3 - Ownership of farm implements 
Russian Journal of Agricultural and Socio-Economic Sciences, 12(24)

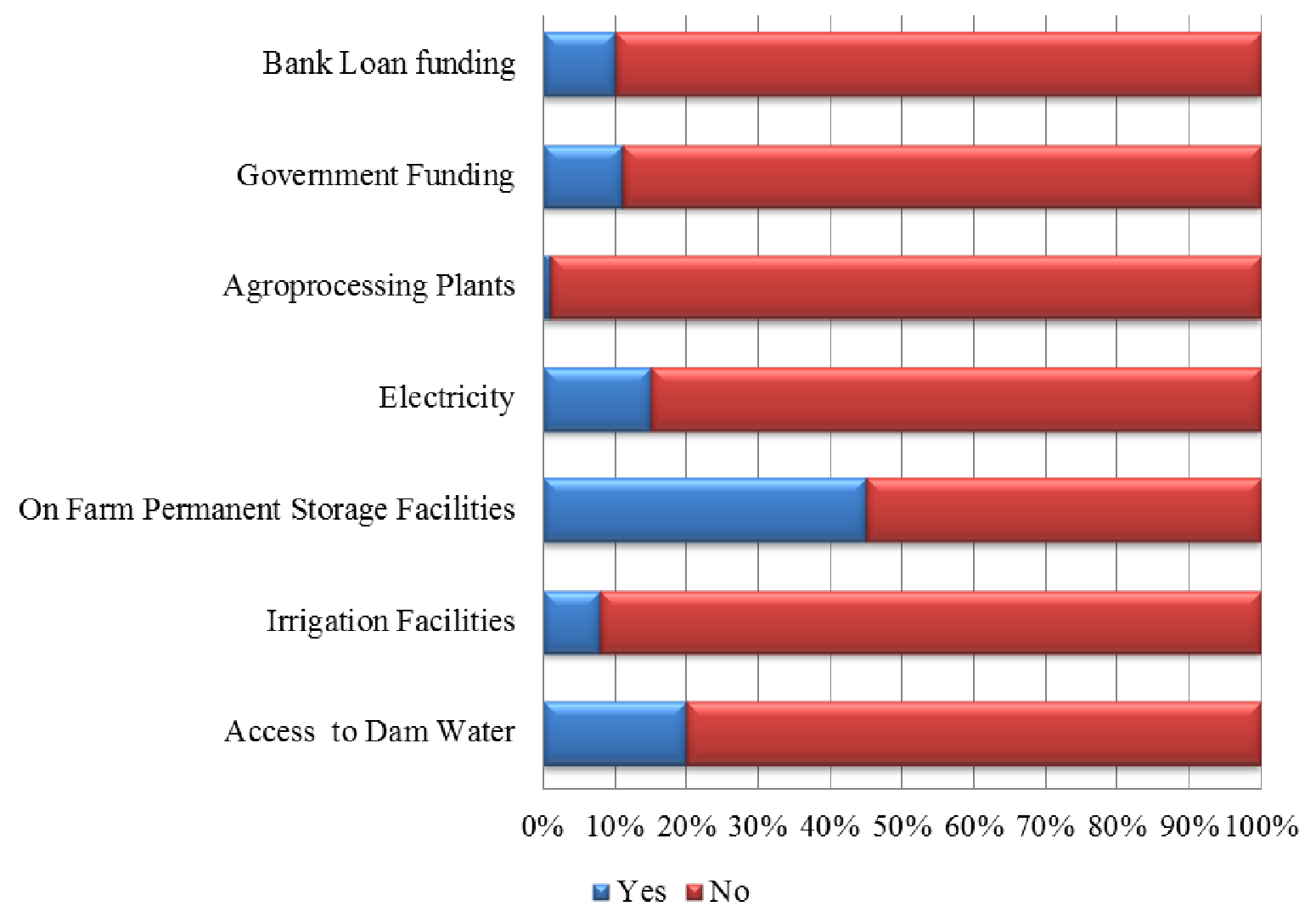

Figure 4 - Access to Agricultural Infrastructure and financing

On Farm Permanent Storage Facilities

Agroprocessing Plants

\section{Electricity}

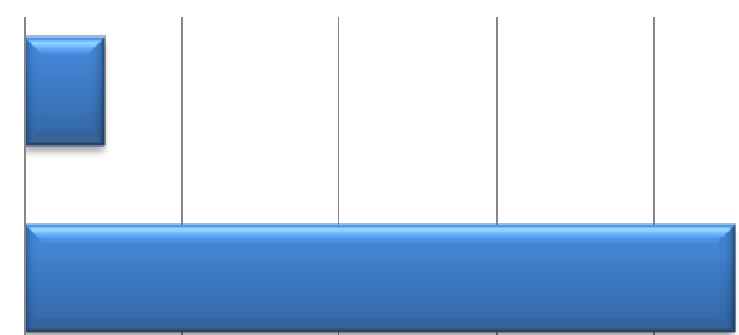

Irrigation Facilities
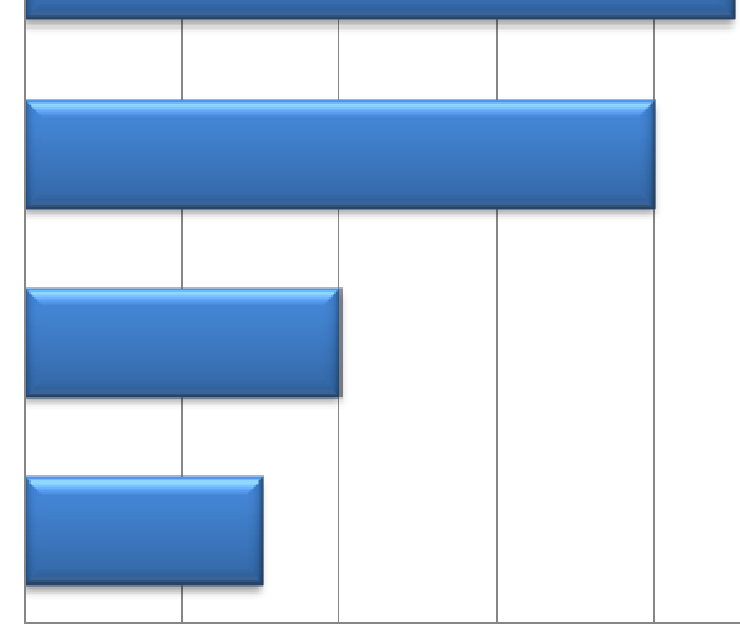

$0 \%$

$20 \%$

$40 \%$

$60 \%$

$80 \% \quad 100 \%$

Figure 5 Working Capacity of Available Infrastructure 


\begin{abstract}
$\square$ Poor road network linking major city
$\square$ Prices too high locally

$\square$ Unavailability of inputs in retail shops

$\square$ High transport costs

$\square$ Lack of information on appropriate inputs $\square$ Overreliance on traditional altenatives
\end{abstract}

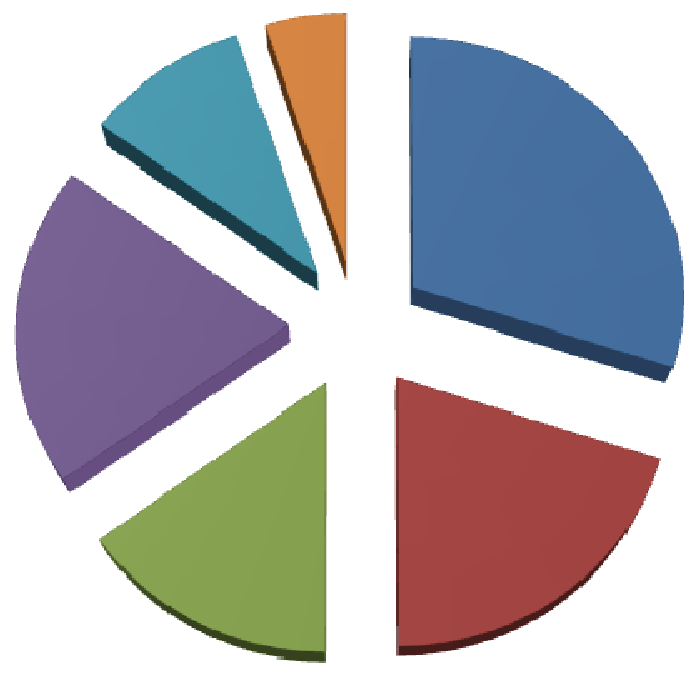

Figure 6 - Factors limiting access to farming inputs

The research conducted on the Model A2 farmers from the Masvingoprovince provided some valuable insights into the challenges that farmers are facing in Zimbabwe after the fast track phase of the land reform programme. The observations and discussions from the focus groups and the information provided for in the questionnaires revealed the following, in line with the purpose of the study;

Poor road network systems. From the research conducted, it was discovered that more than $60 \%$ of the farms are inaccessible by road. The subdivisions that were done to the larger commercial farms to enable resettlements infringed negatively on the already established not network systems. The responsibility for the maintenance of the gravel roads that had previously rested on a single commercial farmer was now shared. Owing to lack of proper maintenance and rampant erosion, most roads have deteriorated. Consequently most farms are not easily accessible by road. Most of the areas in the Zimuto also experienced bad cellular phone reception, andhad noelectricity, making communication even more difficult. From the questionnaires and focus group discussion, it was established that poor transport systems led to delays in receipts of essential agricultural inputs. Retailers who operate in most of these areas are forced to charge higher prices to improve their profit margins. Agricultural extension officers are said to be shunning most areas especially in remote parts of Zimuto because of inaccessibility. All these factors build up to poor agricultural practices and low yields. Most of the largely inaccessible areas had poor harvests and farmers were largely unable to sell their agricultural produce at competitive prices.Studies by Fan and Hazell (2000)in India revealed that government expenditures on roads had the greatest impact on poverty reduction and productivity growth.

Dilapidated infrastructure in rural areas. Observations and input from farmers showed that the existing infrastructure in most farms is dilapidated. Operating capacity of most dams, farming implements and storage facilities is below $40 \%$. Cattle dipping tanks and water holes and irrigation facilities in more than $60 \%$ of the farms were malfunctioning owing to vandalism and lack of maintenance. The respondents attribute this problem to the manner in which the allocation of farms was done, where there was no proper handover takeover procedure and no one was accountable for the property on the farms. As a result some people sought to make a quick return by selling the farm equipment and this had long term effects on sustainable food production. 
Excessive losses on perishable market gardening produce. The majority of farmers in the Zimuto area generate more than $50 \%$ of the agricultural income from farming and selling tomatoes and other market gardening crops. These crops are mainly sold in Masvingo and Gutu and they are perishable. The majority of the farms do not have facilities to process these produce to enable longer life. The produce is sold in Masvingo which is not easily accessible due to poor road network and transport systems. When these crops are in season, farmers lose a lot of produce which go bad. In order to reduce losses, farmers are forced to drive the price down. If tomatoes could be processed into dried tomatoes or tomato puree, farmers would avoid such loses.

\section{CONCLUSIONS AND RECOMMENDATIONS}

Based on the findings of this research, the following recommendations are made to farmers, government private sector and other stakeholders. While these recommendations are not exhaustive, they will go a long way in alleviating the effects of infrastructure deterioration and enable sustainable food production.

Invest in physical and agro-processing infrastructure. In line with the observation by Bhatia (1999) who observe a strong positive relationship between investment in rural infrastructure and the level of per hectare yield of food grains, there is need for government, the private sector and the relevant farmers to invest in infrastructure development. Such an investment will enable intensification and diversification of agricultural activities by enabling access to inputs, markets, education facilities, health services centers and informationcenters. In addition improved access to roads, irrigation facilities, electricity and storage and processing facilities helps improve the standard of living off the people. In line with the recommendation by UN (2010) for Zimbabwe, there is an urgent need for development and rehabilitation of rural agricultural infrastructure, including storage facilities, roads, irrigation, dip tanks, handling pens andmechanization.

Community infrastructure developmentinitiatives. Notably access to infrastructure financing remains limited especially to farmers in the model A2 resettlement areas, mainly because they lack the required collateral and bankable business proposals. However infrastructure development can still be made possible through community initiatives. Instead farmers individually developing their areas, they could achieve better results by working as communities on developmental projects. Pooling resources together could see farmers benefiting from the synergistic effects of working as a team. For example irrigation facilities require much more capital which an individual family may not be able to raise. However if farmers adjacent to each other pool resources together through a well manage process, they could achieve desired results.

Embrace cheap technology. Farmer need to be urged to take advantage of cheap information sources like mobile phones, internet, social media, to access digital agriculture and information farming problems, inputs and markets. While poor physical infrastructure has been hindering movement of agricultural extension officers, the internet is a source of valuable information for farmers. Inaddition instead of the officers travelling, a phone call could help in solving minor problems. Farmers need also be encouraged to embrace and make full use of modern Information and Communication Technology tools to enhance their agricultural productivity and achieve sustainable food production.

Access to infrastructure financing. Through the Agricultural Bank of Zimbabwe and the Infrastructure Development Bank of Zimbabwe, the government could available funding for the rehabilitation of boreholes,dams, road networks and other agricultural mechanization facilities for the resettled farmers. To compliment financing, the government could fast track the rural electrification programme towards resettled A2 farmers as a way of promoting agricultural productivity.

Research and development. Because of the persistent low level of annual harvest, there is need for, over and above infrastructural development, consolidation of the capacity for research, agricultural extension and policy analysis in the areas of crops, livestock, mechanization, water resources development and irrigation, agricultural education, forestry, 
natural resources management, and climate change. Improved institutional capacity for research will provide a long term solution to the problems that the farmers are facing in the rural areas.

In the final analysis, it can be noted that intensive investment in agricultural infrastructure in areas occupied by model A2 farmers will result in an increase in agricultural productivity breeding sustainable food production. Government, private sector and the farmers should work towards finding more permanent solutions to the challenges relating to infrastructure.

\section{REFERENCES}

[1] Ahmed, R., and Hussain, M. (1990) Developmental Impact of Rural Infrastructure in Bangladesh, IFPRI. Research Report 83. Washington, D.C.

[2] Antle, J. M. (1983) Infrastructure and Aggregate Productivity: International Evidence, Economic Development and Cultural Change, 31 (2), 609-620.

[3] Besley, T. and Burgess, R. (2003), "Halving Global Poverty", Journal of Economic Perspectives, Volume 17, 3, 3- 22.

[4] Bhatia, M. S. (1999), Rural Infrastructure and Growth in Agriculture, Economic and Political weekly, Review of Agriculture, 43-53.

[5] Bunch R. and López G. (1996) Soil recuperation in Central America: sustaining innovation after intervention. Gatekeeper Series SA 55, Sustainable Agriculture Programme, IIED, London.

[6] Chen, S., Ravallion, M. (2007) Absolute Poverty Measures for the Developing World, 1981-2004, World Bank, Washington, DC.

[7] Diao, X., Hazell, P., Resnick, D. and Thurlow, J. (2007) The Role of Agriculture in Development: Implications for Sub-Saharan Africa (Research Report 153). International Food Policy Research Institute.

[8] Dobberman and Nelson (2013) Opportunities and Solutions for Sustainable Food Production, Sustainable Development Solutions Network, United Nations.

[9] Fan, S. and Hazell, P., (2000) Should Developing Countries Invest More in LessFavoured Areas? An Empirical Analysis of Rural India, Economic and Political Weekly, April, 1455-1464.

[10] Gajigo, O. and Lukoma, A. (2011) Infrastructure and Agricultural Productivity in Africa, AfDB.

[11] Hinchcliffe, F., Thompson, J. and Pretty, J. N. (1996) Sustainable Agriculture and Food Security in East and Southern Africa. Report for the Committee on Food Security in East and Southern Africa, Swedish International Agency for International Cooperation, Stockholm.

[12] Luebker, M. (2008) Employment, unemployment and informality in Zimbabwe: Concepts and data for coherent policy-making, ILO SRO for Southern Africa, Harare, Zimbabwe, Issues Paper No. 32 and Integration Working Paper No. 90.

[13] Makamure, J., Jowa, J. and Muzuva, H. (2001) Liberalization of Agricultural Markets, SAPRI, Zimbabwe.

[14] Pretty, J.N. (1995) Participatory learning for sustainable agriculture. World Development 23(8), 1247-1263.

[15] Pretty, J.N., Thompson J. and Hinchcliffe, F. (1997) Sustainable Agriculture: Impacts on Food Production and Challenges for Food Security, International Institute for Environment and Development, GS No. 60.

[16] Rosegrant, M. W., and P. Hazell. (2000) Transforming the rural Asian economy: The unfinished revolution. Oxford University Press, Hong Kong.

[17] Rostow, W.W. (1960). The Stages of Economic Growth: A Non-Communist Manifesto, Cambridge University Press, Cambridge, UK.

[18] Schneider, K. and Gugerty, M. K. (2011) Agricultural Productivity and Poverty Reduction: Linkages and Pathways, The Evans School Review, Vol. 1 (1). 
[19] Seidman, A., (1982) A Development Strategy for Zimbabwe, Zambezia, Vol. X (i), 1339.

[20] UN (2010) Country Analysis Report for Zimbabwe, United Nations.

[21] UNDP Sudan (2006) Macroeconomic Policies for Poverty Reduction: The Case of Sudan, UNDP, United Nations.

[22] Venkatachalam, L. (2003) Infrastructure and Agricultural Development in Karnataka State, Institute for Social and Economic Change, Nagarbhavi, Bangalore.

[23] Warner, M., D. Kahan, and S. Lehel. (2008) "Market-Oriented Agricultural Infrastructure: Appraisal of Public-Private Partnerships." FAO, Rome. 